Ball, J. R., P. Sólymos, F. K. A. Schmiegelow, S. Hache, J. Schieck, and E. Bayne. 2016. Regional habitat needs of a nationally listed species, Canada Warbler (Cardellina canadensis), in Alberta, Canada. Avian Conservation and Ecology 11(2):10. http://dx.doi.org/10.5751/ ACE-00916-110210

Copyright (C) 2016 by the author(s). Published here under license by the Resilience Alliance.

Research Paper

\title{
Regional habitat needs of a nationally listed species, Canada Warbler (Cardellina canadensis), in Alberta, Canada
}

Jeffrey R. Ball ${ }^{1,2}$, Péter Sólymos ${ }^{1,3}$, Fiona K. A. Schmiegelow ${ }^{4,5}$, Samuel Hache ${ }^{6}$, Jim Schieck ${ }^{1,3}$ and Erin Bayne ${ }^{1}$ ${ }^{1}$ Department of Biological Sciences, University of Alberta, ${ }^{2}$ Ducks Unlimited Canada, ${ }^{3}$ Alberta Biodiversity Monitoring Institute, University of Alberta, ${ }^{4}$ Department of Renewable Resources, University of Alberta, ${ }^{5}$ Yukon Research Centre, ${ }^{6}$ Environment Canada, Government of Canada

\begin{abstract}
Understanding factors that affect the distribution and abundance of species is critical to developing effective management plans for conservation. Our goal was to quantify the distribution and abundance of Canada Warbler (Cardellina canadensis), a threatened old-forest associate in Alberta, Canada. The Canada Warbler has declined across its range, including in Alberta where habitat loss and alteration from urban expansion, forestry, and energy development are changing the forest landscape. We used 110,427 point count survey visits from 32,287 unique survey stations to model local-level (150-m radius circular buffers) and stand-level (564-m radius circular buffers) habitat associations of the Canada Warbler. We found that habitat supporting higher densities of Canada Warblers was locally concentrated yet broadly distributed across Alberta's boreal forest region. Canada Warblers were most commonly associated with older deciduous forest at the local scale, particularly near small, incised streams, and greater amounts of deciduous forest at the stand scale. Predicted density was lower in other forest types and younger age classes measured at the local scale. There was little evidence that local-scale fragmentation (i.e., edges created by linear features) influenced Canada Warbler abundance. However, current forestry practices in the province likely will reduce the availability of Canada Warbler habitat over time by cutting old deciduous forest stands. Our results suggest that conservation efforts aimed at Canada Warbler focus on retaining large stands of old deciduous forest, specifically stands adjacent to streams, by increasing the width of deciduous retention buffers along streams during harvest and increasing the size and number of old forest residual patches in harvested stands.
\end{abstract}

\section{Besoins régionaux en matière d'habitat d'une espèce inscrite sur la liste nationale d'espèces en péril, la Paruline du Canada (Cardellina canadensis), en Alberta, Canada}

RÉSUMÉ. La compréhension des facteurs qui influent sur la répartition et l'abondance d'une espèce est importante si l'on veut élaborer des plans de gestion efficaces pour sa conservation. L'objectif de notre étude était de quantifier la répartition et l'abondance de la Paruline du Canada (Cardellina canadensis), une espèce menacée associée aux forêts âgées en Alberta, Canada. Les effectifs de la Paruline du Canada ont diminué dans l'ensemble de son aire, y compris en Alberta où la perte et la modification d'habitat attribuables à l'étalement urbain, aux pratiques forestières et aux activités de développement énergétique modifient le paysage forestier. Nous avons utilisé 110427 dénombrements à partir de 32287 stations d'écoute afin de modéliser l'association de la Paruline du Canada avec l'habitat à l'échelle locale (rayon de $150 \mathrm{~m}$ autour de la station) et à celle du peuplement (rayon de $564 \mathrm{~m}$ autour de la station). Nous avons trouvé que les milieux qui hébergeaient les densités les plus élevées de Paruline du Canada étaient concentrés localement, mais aussi très répandus dans la région de la forêt boréale albertaine. Les parulines étaient le plus souvent associées aux forêts décidues âgées à l'échelle locale, en particulier près des petits cours d'eau enclavés, et aux plus grandes étendues de forêts décidues à l'échelle du peuplement. La densité prédite était plus faible dans les autres types forestiers et les forêts de classes d'âge plus jeunes à l'échelle locale. Nos données ne nous ont pas permis d'attester que la fragmentation (c.-à-d. les bordures créées par des interventions linéaires) à l'échelle locale agissait sur l'abondance de la Paruline du Canada. Toutefois, les pratiques forestières courantes dans la province vont vraisemblablement mener à la réduction de la disponibilité de son habitat au fil des ans en raison des coupes de peuplements de forêts décidues âgées. Nos résultats indiquent que les efforts de conservation visant la Paruline du Canada devraient porter sur la rétention de grandes étendues de forêts décidues âgées, surtout les peuplements situés en bordure de cours d'eau; ainsi, nous suggérons d'augmenter la largeur des bandes de forêts décidues résiduelles le long des cours d'eau au moment de la récolte et d'augmenter la taille et le nombre d'îlots résiduels de forêts décidues âgées dans les peuplements récoltés.

Key Words: Canada Warbler; Cardellina canadensis; cumulative effects; habitat suitability; multiple spatial scales; species at risk; species distribution model 


\section{INTRODUCTION}

Loss, fragmentation, and degradation of forests continue to be important factors affecting bird populations globally, including the extensive boreal regions of the world (Robinson and Sherry 2012, Morante-Filho et al. 2015, Pavalacky et al. 2015, Virkkala 2016). Canada's boreal forest is important breeding habitat for nearly half of all North American bird species (Blancher and Wells 2005, Wells and Blancher 2011) and is vital to the Canadian economy because of the abundance of oil, gas, and forest resources in this region (Anielski and Wilson 2009). Understanding the habitat needs of boreal birds, and how accelerating resource development may affect the distribution and abundance of species, is critical to address conservation policy in this region (Rudd et al. 2011).

Our historic understanding of how forest change influences birds comes primarily from studies in eastern North America, where forests are predominantly converted to agriculture. These results may not apply to much of the boreal forest or to forested landscapes in much of western North America (George and Dobkin 2002), where the primary human disturbances are forestry, mining, and energy development, and where disturbed areas of early seral vegetation largely revert back to forests over time (Schmiegelow and Mönkkönen 2002, Lee et al. 2009). In addition, western forests, and the boreal forest in particular, are naturally dynamic because of fire and insect outbreaks. It has been hypothesized that boreal birds may be resilient to humaninduced disturbance that emulates these natural disturbances, particularly in areas with high amounts of suitable habitat remaining (Schmiegelow et al. 1997, Norton et al. 2000, Brotons et al. 2003, Taylor and Krawchuk 2006, Leonard et al. 2008, Whitaker et al. 2008; see also George and Dobkin 2002). Evidence to support this resilience is limited, however (Schmiegelow and Villard 2009), and a number of boreal bird species have recently been identified as at risk in Canada because of observed population declines and associated threats in breeding and wintering areas (NABCI 2012, Environment Canada 2016a, $b$ ).

The Canada Warbler (Cardellina canadensis) is a medium-sized neotropical migrant that breeds across the southern boreal forest of Canada and in forested habitats surrounding the Great Lakes and south through the Appalachian Mountains to northeast Georgia (Reitsma et al. 2010). The species is of conservation concern in North America (Rich et al. 2004) and was assessed as threatened by the Committee on the Status of Endangered Wildlife in Canada in response to significant long-term declines $(-2.9 \%$ annual population change in Canada between 1970 and 2012; Environment Canada 2014) and because $>80 \%$ of the breeding population occurs in Canada (COSEWIC 2008). Despite their broad distribution and recognized conservation status, few studies have focused on the Canada Warbler, and their ecology is poorly understood, particularly in the western part of their range. Declines appear more prominent in eastern than western North America (Rich et al. 2004, Reitsma et al. 2010, Sauer et al. 2014) and may reflect regional differences in habitat associations and local drivers on both the breeding and wintering grounds. In the east, Canada Warblers breed in young forest stands, mature swamp forests, and mature riparian forests with a dense shrub understory and emergent song-perch trees (Hallworth et al. 2008a, b, Reitsma et al. 2008, Goodnow and Reitsma 2011). Canada Warblers are also associated with forest disturbance that creates suitable understory conditions, particularly at higher elevations and in the southern portion of their range (Lambert and Faccio 2005, Becker et al. 2012). Declines in the eastern portion of their range may be related to forest succession and the loss of important structural stand elements associated with disturbed areas (Reitsma et al. 2010). Short harvest rotations and loss of older forest age classes may also be contributing to their decline (Grinde and Niemi 2016).

Canada Warbler abundance in Alberta has declined since 1966 (ESRD 2010, Sauer et al. 2014), and the species is listed as sensitive in the province (CESCC 2011). There has been speculation that causes of this decline might include habitat loss and habitat alteration from industrial development and changes in forest succession patterns on the breeding grounds (ESRD 2010, Reitsma et al. 2010). Local-scale studies in western Canada have suggested the Canada Warbler is a habitat specialist, defending territories on steep slopes and near streams in mature and old mixed wood, aspen-dominated, or poplar-dominated forests with a dense woody understory (Schieck et al. 1995, Stelfox 1995, Cooper et al. 1997, Schieck and Song 2006). However, studies also report the Canada Warbler in early seral vegetation with brushy edges and residual patches of live trees (Schieck et al. 2000, Schieck and Hobson 2000, Schieck and Song 2006; reviewed by Reitsma et al. 2010). Canada Warblers also may not avoid edges created by human development, but may increase territory size and incorporate smaller clearings within their defended space (Machtans 2006). Clearly, refined understanding of the local habitat needs of Canada Warblers and how these are influenced by various types of human activities that alter the age structure, spatial pattern, and composition of their habitat is needed, particularly at large spatial extents.

Our goal was to evaluate how forest structure and composition influence the local density of Canada Warblers in boreal Alberta, using the best available information. Although considerable population declines have been reported in Alberta ( $-3.74 \%$ annual population change between 1975 and 2012), data deficiencies (North American Breeding Bird Survey [BBS] trend reliability in Alberta is "low"; Environment Canada 2014) have prevented accurate assessment of their current distribution, habitat associations, and whether or not current land use practices in the province may have contributed to declines (Rich et al. 2004, Sauer et al. 2014). Based on our current understanding of habitat associations in the western boreal forest described above, we predicted that Canada Warblers would be most abundant in older deciduous-dominated forest, particularly near small, incised streams, and potentially in early seral forests with dense shrubs and large patches of residual trees. We did not predict a strong negative effect of linear features on abundance so long as large amounts of suitable forest cover remained.

\section{METHODS}

\section{Bird data}

We used 110,427 point count survey visits from 32,287 unique survey stations in the Boreal, Foothills, Parklands, and Rocky Mountain natural regions north of $50^{\circ}$ latitude in Alberta, Canada. Survey data were collated from the BBS (46,982 visits), Boreal Avian Modelling Program (52,690 visits; http://www. borealbirds.ca; database version 4), and the Alberta Biodiversity 
Monitoring Institute (10,755 visits; http://www.abmi.ca). Surveys were conducted between 1997 and 2015 during studies and monitoring programs not specifically targeted at the Canada Warbler. In combination, these surveys are reasonably representative of Alberta's boreal region, although areas of the Rocky Mountain natural region and the far north have comparatively fewer samples (Fig. 1). Each survey was 3 (45.9\%), $5(26.9 \%)$, or $10(27.3 \%)$ minutes long and sampled a radius of $50 \mathrm{~m}$ to unlimited distance $(2.5 \% 50 \mathrm{~m}, 22.6 \% 100 \mathrm{~m}, 0.1 \% 150$ $\mathrm{m}, 74.8 \%$ unlimited). Most locations (91.6\%) were surveyed once in any given year, and $6681(20.7 \%)$ locations were visited in two or more years. One or more Canada Warblers were detected during $1611(1.46 \%)$ surveys at $1050(3.25 \%)$ locations, with a maximum record of four individuals in a survey.

Fig. 1. The spatial distribution of survey locations and Canada Warbler detections within the northern Alberta study area used to model habitat associations and distributions.

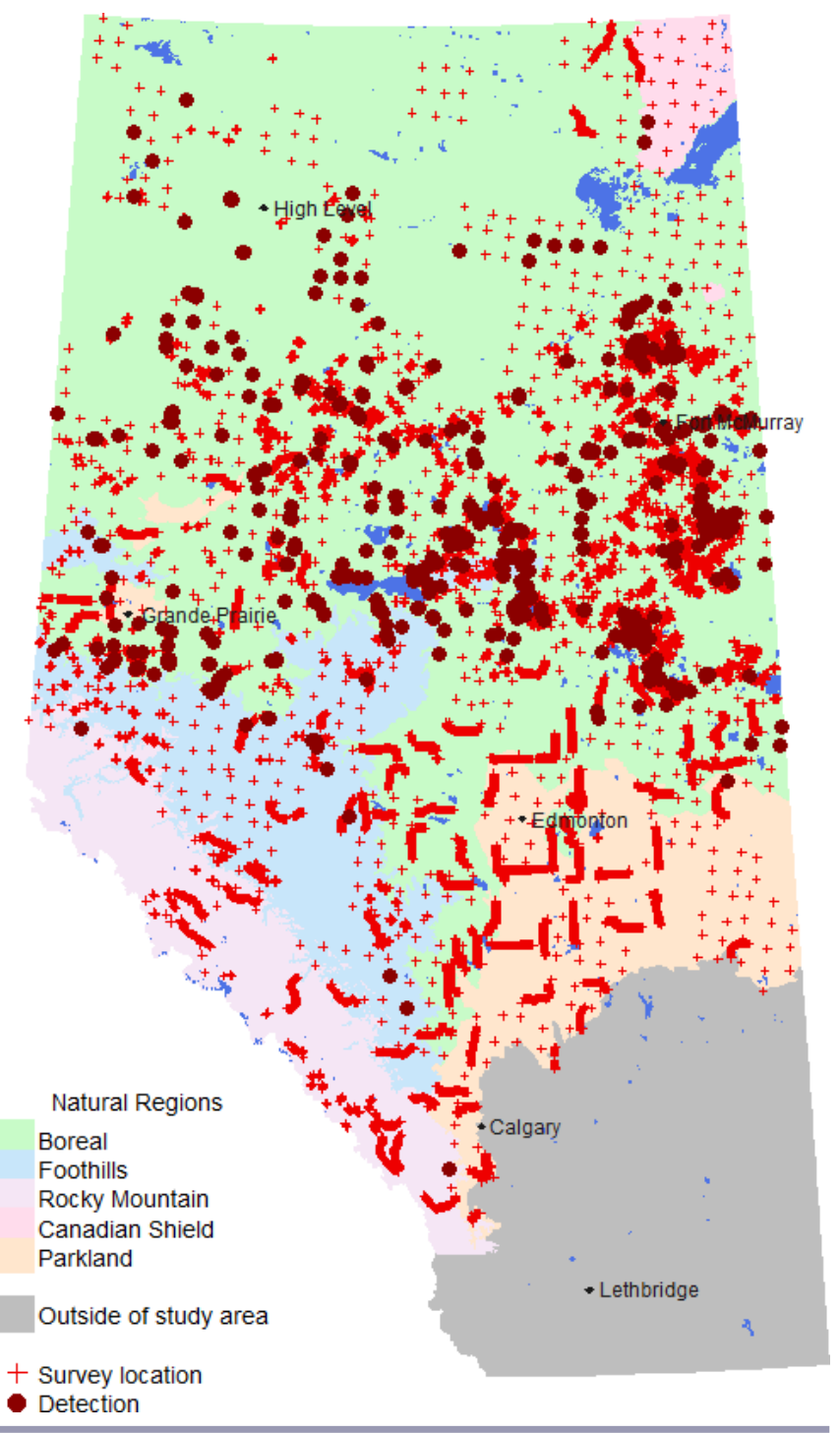

\section{Biophysical attributes}

Breeding habitat selection occurs at multiple scales (Johnson 1980). We used two spatial scales to derive predictor variables for each survey station. Local-scale variables were assessed in a 150$\mathrm{m}$ radius of each station. This scale encompasses the average breeding territory of Canada Warbler (1 ha; Reitsma et al. 2010) and the effective detection distance for the song of most forest songbirds (Matsuoka et al. 2012). It is also half the minimum distance between stations in our data set. Stand-scale variables were assessed in a 564-m radius $\left(1 \mathrm{~km}^{2}\right)$ of each survey station. This stand scale was chosen for pragmatic reasons to match the mapping unit in our predictions and because it roughly corresponds to the scale deemed most appropriate for landscape variables (smoothing kernel estimate for landscape variables approached 0 at approximately 500-m distance; Chandler and Hepinstall-Cymerman 2016). However, some warblers have been shown to disperse up to $500 \mathrm{~m}$ from their natal territory postfledge, suggesting habitat selection may also be operating at this scale (Streby and Andersen 2013).

Predictor variables were chosen based on our current understanding of Canada Warbler habitat associations and abiotic parameters that potentially influence their distribution across the province (AESRD and ACA 2014). At the local scale, land cover was assessed for each survey station using provincial land cover (HAB; see Table 1) information (ABMI 2013a, 2015). Vegetation type included deciduous, mixed wood, white spruce, pine, black spruce, and larch-dominated forest stands, and shrub, grass/herb, swamp, wet grass, and wet shrub cover types. Human footprint was assessed at each survey point based on the year of sampling (interpreted at a 1:5000 scale; Schieck et al. 2014). Footprint type included cultivation, forestry, urban-industrial, hard linear (road and rails), and vegetated soft linear (seismic lines, pipe lines, power lines) features.

Proportional area was calculated at the local scale, and the dominant vegetation type, which in $95 \%$ of the cases comprised $\geq 50 \%$ of the area, was assigned to each survey station based on a simple majority rule. We used various data sources (ABMI 2015) to estimate the years since last disturbance (YSD; i.e., forest age) relative to year of sampling for birds. YSD was calculated as the area weighted average of the geographic information system (GIS) polygons within each buffer distance (local and stand scales). We modeled the effect of forest age on Canada Warbler density by using YSD and its quadratic and square root transformed terms as covariates. We incorporated interactions between forest type and age (Table 2). When the dominant land cover was a harvest block, the predisturbance vegetation type was assumed based on available forest inventory data in the local 150$\mathrm{m}$ buffer (ABMI 2015). Doing so treated harvested areas as young forest rather than a separate land cover type. We also created a contrast variable that ranged between 1 (recent harvest) and 0 (converged to natural stands) to describe the convergence trajectory of forestry cut blocks. We assumed that convergence is complete at 60 years after harvest. This allowed us to differentiate young forests of natural (i.e., fire) versus anthropogenic (i.e., timber harvest) origin. 
Table 1. Definition of model terms that were selected at least once in modeling with the range of values in the data set.

\begin{tabular}{|c|c|c|}
\hline Term & Definition & Values or range \\
\hline HAB & Land cover type & 13 classes \\
\hline YSD & Years since disturbance & $0-160 \mathrm{yrs}$ \\
\hline is $M$ & Indicator variable for mixedwood & 0,1 \\
\hline is $\mathrm{P}$ & Indicator variable for pine forest & 0,1 \\
\hline isW & Indicator variable for white spruce forest & 0,1 \\
\hline is $\mathrm{C}$ & $\begin{array}{l}\text { Indicator variable for conifer (pine, white } \\
\text { spruce, black spruce, or larch) }\end{array}$ & 0,1 \\
\hline is $U C$ & $\begin{array}{l}\text { Indicator variable for upland conifer (pine or } \\
\text { white spruce) }\end{array}$ & 0,1 \\
\hline isLC & $\begin{array}{l}\text { Indicator variable for lowland conifer (black } \\
\text { spruce or larch) }\end{array}$ & 0,1 \\
\hline FOR & Forestry contrast relative to natural origin & $0-1$ \\
\hline ROAD & Indicator variable for roadside surveys & 0,1 \\
\hline SLIN & $\begin{array}{l}\text { Vegetated linear features at } 150-\mathrm{m} \text { buffer } \\
\text { scale }\end{array}$ & $0-72 \%$ \\
\hline ARU2 & Recording technology contrast & 2 classes \\
\hline ARU3 & Recording technology contrast & 3 classes \\
\hline WET & Wet land cover at $150-\mathrm{m}$ buffer scale & $0-100 \%$ \\
\hline CTI & Compound topographic index & $5.0-26.8$ \\
\hline LAT & Latitude & $\begin{array}{l}50.27-60.01 \\
\text { degrees }\end{array}$ \\
\hline LON & Longitude & $\begin{array}{l}-120 \text { to }-110 \\
\text { degrees }\end{array}$ \\
\hline PET & Potential evapotranspiration & $288-645$ \\
\hline MAT & Mean annual temperature & -4.6 to $3.6^{\circ} \mathrm{C}$ \\
\hline MAP & Mean annual precipitation & $347-1902 \mathrm{~mm}$ \\
\hline FFP & Frost free period & 46-122 days \\
\hline AHM & Annual heat-moisture index & $4.4-34.7$ \\
\hline MWMT & Mean warmest month temperature & $7.2-17.7^{\circ} \mathrm{C}$ \\
\hline MCMT & Mean coldest month temperature & -27.1 to $-8.7^{\circ} \mathrm{C}$ \\
\hline DECO & Old growth deciduous forest at $1 \mathrm{~km}^{2}$ scale & $0-100 \%$ \\
\hline DMO & $\begin{array}{l}\text { Old growth deciduous and mixedwood forest } \\
\text { at } 1 \mathrm{~km}^{2} \text { scale }\end{array}$ & $0-100 \%$ \\
\hline DEC & Deciduous forest at $1 \mathrm{~km}^{2}$ scale & $0-100 \%$ \\
\hline DM & $\begin{array}{l}\text { Deciduous and mixedwood forest at } 1 \mathrm{~km}^{2} \\
\text { scale }\end{array}$ & $0-100 \%$ \\
\hline THF & Total human footprint at $1 \mathrm{~km}^{2}$ scale & $0-100 \%$ \\
\hline SUCC & Successional footprint at $1 \mathrm{~km}^{2}$ scale & $0-100 \%$ \\
\hline ALIEN & Alienating footprint at $1 \mathrm{~km}^{2}$ scale & $0-100 \%$ \\
\hline LIN & Linear features at $1 \mathrm{~km}^{2}$ scale & $0-46 \%$ \\
\hline NLIN & THF-LIN (nonlinear) & $0-100 \%$ \\
\hline YR & Year & $1997-2015$ \\
\hline
\end{tabular}

Hard and soft vegetated linear features were never the dominant land cover and were dropped from the list of local-scale land cover categories. We modeled their effect based on a dummy variable for the presence of a road in the 150-m buffer (i.e., roadside surveys) and the proportion of vegetated linear features, because it is known that their presence can introduce biases when not accounted for (Marques et al. 2010, Bayne et al. 2016). We also accounted for biases related to survey methodology. The majority of the surveys $(85.3 \%)$ were done by trained human observers, whereas the remainder were field-based recordings (RiverFork units [ $8.5 \%$ of surveys]; SongMeter units [ $6.2 \%$ of surveys]), which were transcribed in the laboratory. We used either a two-level (ARU2: human vs. recordings) or a three-level (ARU3: human, RiverFork, SongMeter) factor variable to account for this possible bias in our analyses. The exponent of these estimated contrasts gave the magnitude of expected counts compared with the reference type of survey method (e.g., off-road survey by a human observer). The ARU2 and ARU3 related estimates $(\delta)$ were
Table 2. Models pertaining to each stage of the branching hierarchy model building process. Descriptions of variable name abbreviations are provided in the Table 1. Colon (:) means interaction, terms in square brackets with a multiplication sign $(\times)$ expand to main effects and interaction term (i.e., $\mathrm{A} \times \mathrm{B}=\mathrm{A}$ $+\mathrm{B}+\mathrm{A}: \mathrm{B}) ; \mathrm{NULL}=$ no terms added at that stage. Selection percentage refers to the number of times the model terms were selected out of 240 bootstrap runs. Models that were not selected at least once were omitted from the table. Area under the receiver operating characteristic curve (AUC) is noted for each model stage based on $10 \%$ holdout validation data.

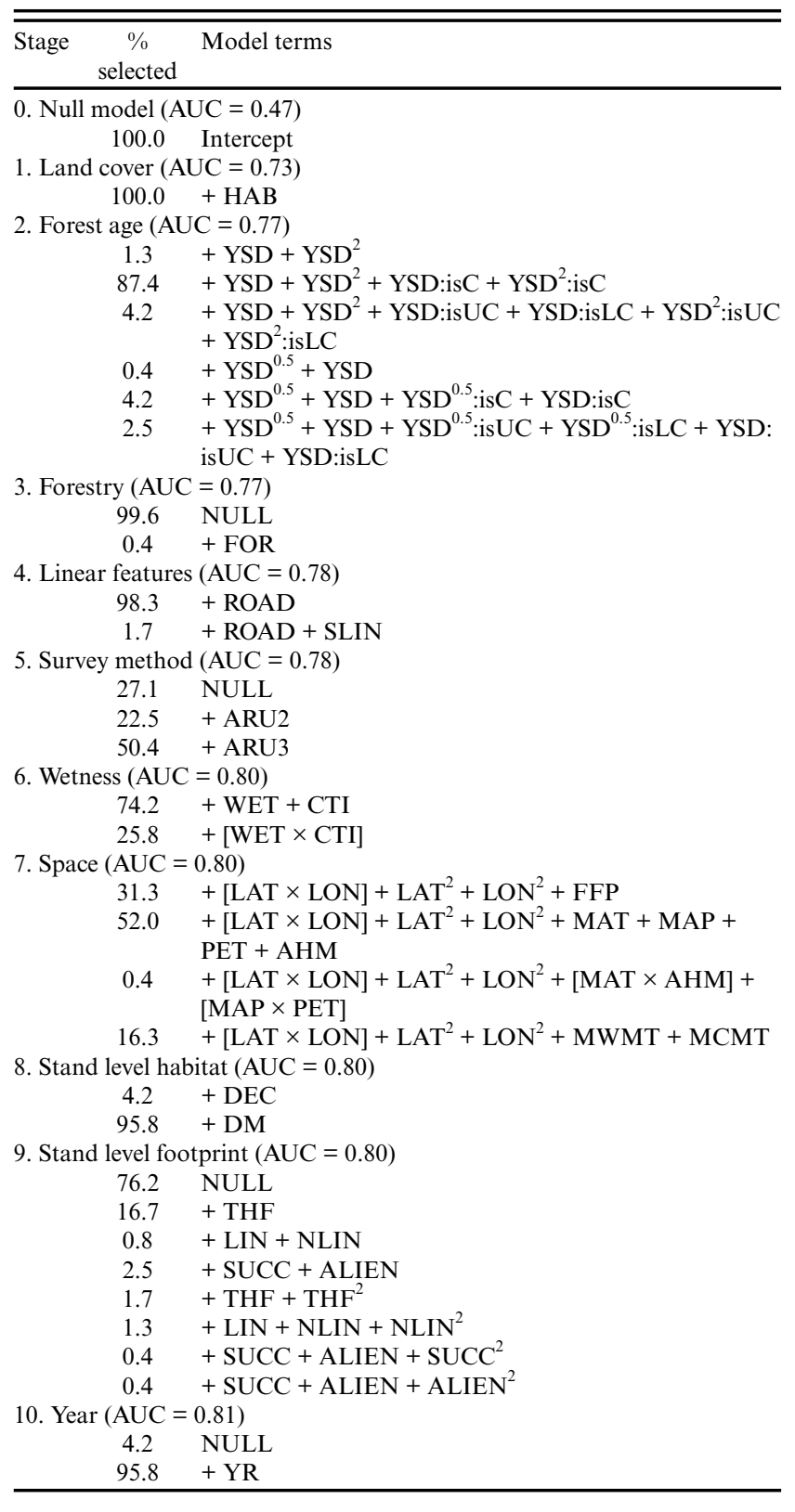

converted to reflect relative differences in effective detection radius $\left(\mathrm{sqrt}\left[\mathrm{e}^{\delta}\right]\right.$ ). The conversion follows from dividing the expected values of the counts from unlimited distance ARU- 
Fig. 2. Probability of availability (range: 0.43-0.99) as a function of survey date (ordinal day: day of year) and survey time (hours since local sunrise) and given point count duration of 3 minutes (A); and probability of perceptibility (range: 0.69-0.99) as a function of habitat type and tree cover (B) and given 100-m point count radius. Dark shades in legend indicate higher probabilities.

A

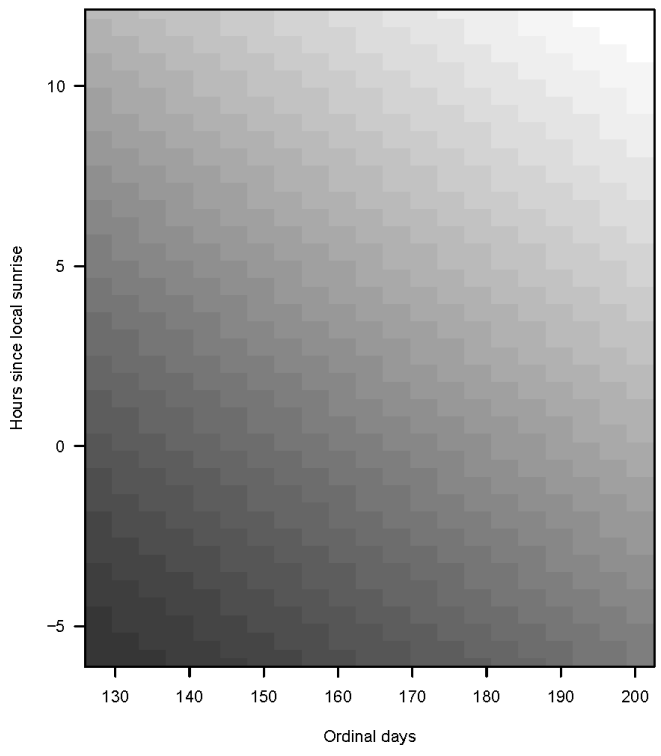

B

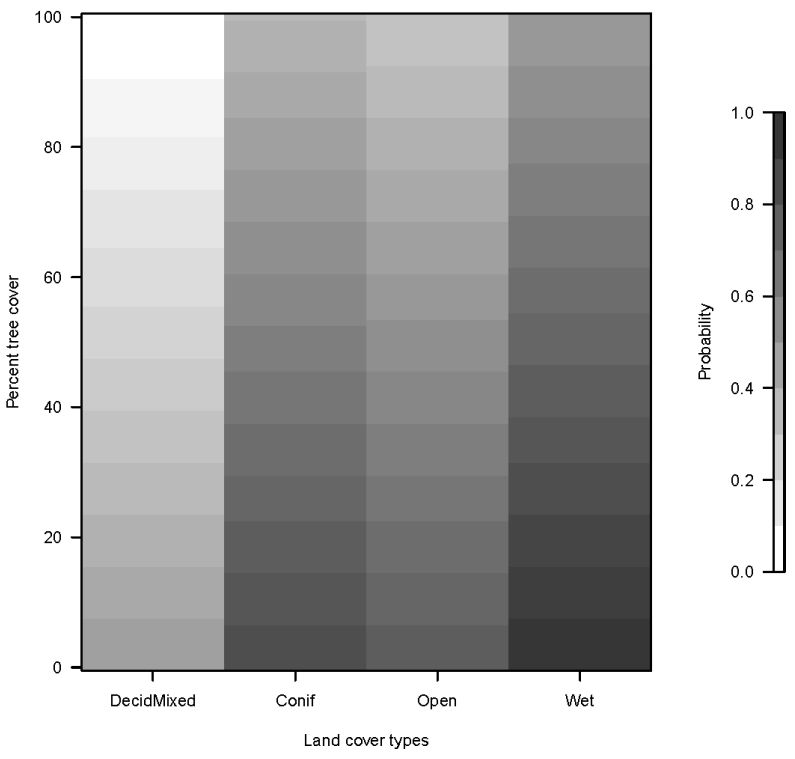

based counts (S. L. Van Wilgenburg, P. Solymos, K. J. Kardynal, and M. D. Frey, unpublished manuscript).

Wetness (Wet) at the local scale was calculated as the proportion of wet areas within $150 \mathrm{~m}$ of each survey station (ABMI 2015). Compound topographic index (CTI), which represents soil moisture as a function of slope and catchment area, was assessed for each survey station using a digital elevation model with 100$\mathrm{m}$ resolution (Moore et al. 1993, Gessler et al. 1995). Low CTI values represent small catchment areas with steep slopes.

Latitude (LAT), longitude (LON), mean annual precipitation (MAP), mean annual temperature (MAT), potential evapotranspiration (PET), annual heat moisture index (AHM), frost-free period (FFP), and mean warmest and coldest month temperature (MWMT, MCMT) were assigned to each survey station to account for geographical patterns in abundance. Climate variables (MAP, MAT, PET, AHM, FFP, MWMT, MCMT) were calculated at a 4-km resolution using monthly climate normal values for temperature and precipitation averaged over 1961-1990. The monthly climate normal values were based on instrumentmeasured climate data that were interpolated at 500-m resolution by PRISM (Daly et al. 2002) and WorldClim (Hijmans et al. 2005). The western North American portion of these data is described by Wang et al. (2012). Linear and quadratic geographic variables, and interactions among them and among climatic variables, were considered (Table 2).

At the stand scale, based on known habitat association of the species, we calculated the proportion of deciduous forest (DEC), mixed wood and deciduous forests combined (DM), old ( $>80$ years) deciduous forest (DECO), and old mixed wood and deciduous forests combined (DMO) within a $564 \mathrm{~m}$ radius of each survey station. Area of total human footprint (THF) was also quantified at the stand scale for each survey station, and further partitioned as proportion of successional (SUCC), alienating (ALIEN), linear (LIN), and nonlinear (NLIN) footprints. Successional footprint included activities where the soil disturbance was minimal (forest harvest, soft linear features), whereas alienating footprint included activities that disturbed soils (cultivation, urban-industrial, hard linear features, humancreated water bodies). Finally, we included a linear year (YR) effect to account for temporal variation in Canada Warbler densities.

\section{Modeling}

We used Poisson generalized linear models with a log link. The response variable was the number of Canada Warblers counted per survey. We used the QPAD approach to account for differences in sampling protocol and nuisance parameters affecting detectability (time of day, time of year, tree cover, habitat composition; Sólymos et al. 2013, Sólymos 2016). This approach converts sampling distances and durations to a common standard through statistical offsets and adjusts for differences in detection error and sampling area related to broad vegetation types and timing of surveys. The QPAD correction included time-varying singing rate estimates. Singing rates were used to estimate the probability of a Canada Warbler being present and giving a cue that could be counted by the observer. Singing rate ranged between 0.43 and 0.99 depending on conditions. This effectively corrects for detection error (see Fig. 2A). We also calculated an effective detection radius (EDR) that uses distance sampling to determine the area sampled. EDRs are dependent on tree cover and habitat composition at the survey point, and estimated values ranged between $73 \mathrm{~m}$ and $92 \mathrm{~m}$ (Fig. 2B). 
We applied "branching" forward stepwise variable selection to minimize bias in predictions. We used an a priori branching hierarchy based on habitat selection principles (Johnson 1980). The branching process was applied instead of a simple add-one type of variable search to make variable selection computationally more efficient by narrowing the scope of potential predictors entering the active set at each stage (see stages in Table 2). At each stage of the branching hierarchy, we compared support among candidate models using Schwartz's information criterion. Variables for the top-ranked model in a given stage were fixed and added to models in the subsequent stage. Model sets at each stage also considered a null model, which was the top model from the previous level or, in the case of the first stage, a constant density model without covariates. Space (stage 7) and stand-scale effects (stages 8-9) modified local effects (stages 1-6; Table 2) at each point depending on habitat composition and disturbance context; year effects were incorporated in the final stage (stage 10).

The model selection procedure was repeated by combining the branching process with bootstrap aggregation ("bagging," Breiman 1996, or "bootstrap smoothing," Efron 2014). Bootstrap replicates were drawn with replacement from each spatiotemporal block to ensure representation of the entire sample distribution. Temporal blocks were set using five-year intervals over the two decades of the study. Spatial blocks were defined based on natural regions (Foothills, Parkland, Rocky Mountain, Boreal). Because of its comparatively large area, the Boreal natural region (including the Canadian Shield) was further subdivided into four quadrants by the $56.5^{\circ}$ parallel and the -115.5 meridian. Within spatial units, we sampled survey stations and survey visits within each selected station with replacement, to retain the spatial sampling pattern of the surveys in the bootstrap samples. When more than one visit occurred at the same location in the same year, we randomly selected a single visit for each of the bootstrap iterations. Observations were assumed to be independent, conditional on the value of the predictors. The number of bootstrap iterations was 239 , plus the original model fit with all data, for a total of 240 independent runs. We stored the IDs of the best supported models at each level of each iteration to enable recovery of the variable selection process.

We used $90 \%$ of the unique location-year combinations in the data as a training set and held out the remaining $10 \%$ of the data as a validation set. We calculated the bootstrap averaged $(B=$ 240) prediction for each data point in the validation set given the values of the predictors, including the QPAD offsets. We then constructed receiver operating characteristic (ROC) curves by plotting sensitivity and specificity based on the predicted values and the dichotomized observations (detection vs. nondetection) to assess model performance. We calculated area under the curve (AUC) as a measure of classification accuracy (Table 2).

Population trends were assessed based on the year effect estimate $(\beta)$, which we converted to percent annual change $\left(100 \times\left[e^{\beta}-1\right]\right)$. This estimate reflects change after accounting for all the other (land cover, climate, topography, disturbance) effects. We used the $\mathrm{R}$ language ( $\mathrm{R}$ Core Team 2016) for data processing (mefa4 package; Sólymos 2009), analysis (glm function), and prediction. ROC curves and AUC were calculated using the $\mathrm{pROC} R$ package (Robin et al. 2011).

\section{Prediction}

We summarized provincial land cover information (ABMI 2013a, 2015; interpreted at a 1:15,000 scale) for the entire study area and calculated average Canada Warbler density (males per ha) for $568,8901 \mathrm{~km}^{2}$ units (i.e., stand scale). Stand-level attributes (footprint and forest composition) were calculated for each unit based on all polygon attributes found within that unit. The centroid of the unit was used to assign latitude, longitude, and climate variable values. Local-scale variables (HAB, YSD relative to the year 2012, which corresponds to the year of the most recent provincial human footprint inventory) were determined for each stand type-age polygon within each $1 \mathrm{~km}^{2}$ unit using the same approach applied for the $150-\mathrm{m}$ radius buffers. Predicted Canada Warbler density for each $1 \mathrm{~km}^{2}$ unit was the area-weighted average of the polygon-level densities. This procedure was repeated for all 240 bootstrap runs using the estimated coefficient matrix based on model stages 1-9. Point prediction for each $1 \mathrm{~km}^{2}$ unit was calculated as the mean of the 240 predicted values. We calculated the coefficient of variation (standard deviation/mean across bootstrap runs) for each unit as an estimate of prediction uncertainty. Population size of males for the study area was calculated by converting densities to abundance in each $1 \mathrm{~km}^{2}$ (density $\times$ area of terrestrial land base in pixels) unit and summing the unit-level values.

\section{RESULTS}

The interactive effect of land cover (HAB) and YSD (linear or quadratic) at the local scale received considerable support for affecting Canada Warbler density (cumulative model selection frequency $=98.3 \%$; stage 2 , Table 2). Canada Warblers showed a strong association with older deciduous (and to a lesser degree older mixed wood) forests compared with younger age classes and other forest types (Table 3). Forest age differences were not as pronounced in coniferous stands. Habitats classified as swamps and shrubby lowland areas showed intermediate suitability for Canada Warblers. Based on low estimated population densities, open and shrubby upland habitats and all types of human footprint constituted low suitability habitats for Canada Warblers (Table 3). Young forest stands were unsuitable for the species irrespective of natural (fire) or anthropogenic (cut block) origin; model selection frequency for forestry effect was $0.4 \%$; stage 3 , Table 2 .

The effect of roads at the local scale was supported by $100 \%$ selection frequency (stage 4, Table 2). Canada Warbler abundance at sites with roads at the local scale was $79 \%$ of off-road counts (90\% confidence interval [CI]: 60\%-100\%). Survey methodology effects because of different effective areas sampled by human observers or recordings units were supported in $72.9 \%$ of the bootstrap runs (stage 5, Table 2). Effective area sampled relative to human observers by RiverForks units was $122 \%(90 \% \mathrm{CI}$ : $100 \%-151 \%$ ) and by SongMeters it was 63\% (90\% CI: $1 \%-100 \%)$.

The additive and interactive effects of Wetness and CTI were selected in all bootstrap runs (stage 6, Table 2). Canada Warbler density increased with decreasing CTI values (Fig. 3). Density also increased by decreasing proportions of wet areas within the 15-m buffer (Fig. 3). Together these variables indicate an association with locations near incised streams at the local scale as opposed to broad, wet areas. 
Table 3. Predicted population density (males/ha) and population size (singing males in thousands) of Canada Warbler in northern Alberta summarized by land cover types (base year for human footprint is 2012). Area gives the total extent of land cover types in the study area, and percent reflects population size relative to the combined total population size. Bootstrap averaged means and lower (5\%) and upper $(95 \%)$ prediction intervals are provided corresponding to $90 \%$ coverage. Land cover types are ranked by mean density.

\begin{tabular}{|c|c|c|c|c|c|c|c|c|}
\hline \multirow[t]{2}{*}{ Land cover class } & \multicolumn{3}{|c|}{ Density (males/ha) } & \multicolumn{3}{|c|}{ Population size (1000s of males) } & \multirow{2}{*}{$\begin{array}{l}\text { Area } \\
\qquad\left(\mathrm{km}^{2}\right)\end{array}$} & \multirow{2}{*}{$\begin{array}{c}\text { Percent } \\
(\%)\end{array}$} \\
\hline & Mean & $5 \%$ & $95 \%$ & Mean & $5 \%$ & $95 \%$ & & \\
\hline Deciduous $>80 \mathrm{yr}$ & 0.0283 & 0.0242 & 0.0334 & 126.3 & 107.9 & 148.7 & 44,559 & 31.9 \\
\hline Mixedwood $>80 \mathrm{yr}$ & 0.0195 & 0.0144 & 0.0245 & 24.9 & 18.5 & 31.4 & 12,823 & 6.3 \\
\hline Swamp & 0.0165 & 0.0075 & 0.0297 & 33.7 & 15.3 & 60.9 & 20,483 & 8.5 \\
\hline Deciduous $<80$ yr & 0.0125 & 0.0101 & 0.0161 & 65.0 & 52.6 & 83.8 & 52,018 & 16.4 \\
\hline Wet, shrub & 0.0123 & 0.0062 & 0.0214 & 42.0 & 21.1 & 73.0 & 34,085 & 10.6 \\
\hline Energy, vegetated linear & 0.0082 & 0.0065 & 0.0106 & 5.7 & 4.5 & 7.3 & 6917 & 1.4 \\
\hline Coniferous $>80 \mathrm{yr}$ & 0.0061 & 0.0035 & 0.0091 & 18.2 & 10.3 & 27.1 & 29,713 & 4.6 \\
\hline Forestry & 0.0061 & 0.0042 & 0.0088 & 15.6 & 10.8 & 22.5 & 25,635 & 3.9 \\
\hline Black spruce $>80 \mathrm{yr}$ & 0.0052 & 0.0022 & 0.0098 & 24.3 & 10.3 & 46.1 & 47,084 & 6.2 \\
\hline Mixed wood $<80 \mathrm{yr}$ & 0.0046 & 0.0032 & 0.0066 & 4.0 & 2.7 & 5.6 & 8583 & 1.0 \\
\hline Larch $>80 \mathrm{yr}$ & 0.0042 & 0.0000 & 0.0097 & 4.0 & $<0.1$ & 9.3 & 9524 & 1.0 \\
\hline Coniferous $<80 \mathrm{yr}$ & 0.0033 & 0.0019 & 0.0056 & 3.9 & 2.2 & 6.6 & 11,883 & 1.0 \\
\hline Larch $<80 \mathrm{yr}$ & 0.0028 & 0.0000 & 0.0064 & 1.8 & $<0.1$ & 4.1 & 6510 & 0.5 \\
\hline Transportation & 0.0028 & 0.0019 & 0.0041 & 1.2 & 0.8 & 1.8 & 4286 & 0.3 \\
\hline Black spruce $<80 \mathrm{yr}$ & 0.0027 & 0.0007 & 0.0048 & 10.6 & 2.9 & 18.8 & 38,764 & 2.7 \\
\hline Pine $<80$ yr & 0.0017 & 0.0009 & 0.0029 & 4.0 & 2.0 & 6.9 & 23,782 & 1.0 \\
\hline Miscellaneous footprint types & 0.0015 & 0.0003 & 0.0030 & 0.1 & $<0.1$ & 0.2 & 700 & $<0.1$ \\
\hline Wet, grass/herb & 0.0013 & 0.0000 & 0.0041 & 1.4 & $<0.1$ & 4.4 & 10,601 & 0.4 \\
\hline Pine $>80 \mathrm{yr}$ & 0.0009 & 0.0004 & 0.0015 & 2.2 & 1.0 & 3.6 & 23,691 & 0.6 \\
\hline Rural-urban & 0.0008 & 0.0002 & 0.0017 & 0.3 & 0.1 & 0.7 & 4206 & 0.1 \\
\hline Mine, well & 0.0008 & 0.0002 & 0.0017 & 0.3 & 0.1 & 0.6 & 3166 & 0.1 \\
\hline Agriculture & 0.0007 & 0.0003 & 0.0011 & 5.8 & 2.8 & 9.5 & 85,224 & 1.5 \\
\hline Grass/herb & $<0.0001$ & $<0.0001$ & $<0.0001$ & $<0.1$ & $<0.1$ & $<0.1$ & 9769 & $<0.1$ \\
\hline Shrub & $<0.0001$ & $<0.0001$ & $<0.0001$ & $<0.1$ & $<0.1$ & $<0.1$ & 9837 & $<0.1$ \\
\hline Combined & 0.0075 & 0.0061 & 0.0098 & 395.3 & 331.8 & 498.5 & 523,845 & 100.0 \\
\hline
\end{tabular}

Fig. 3. Predicted density (males/ha) as a function of wetness in $150-\mathrm{m}$ buffers centered around survey locations and compound topographic index (CTI) at 100-m resolution. Darker shades correspond to higher density, and contours indicate equal density (males/ha) values. Points show the distribution of survey locations with (filled) and without (open) Canada Warbler detections.

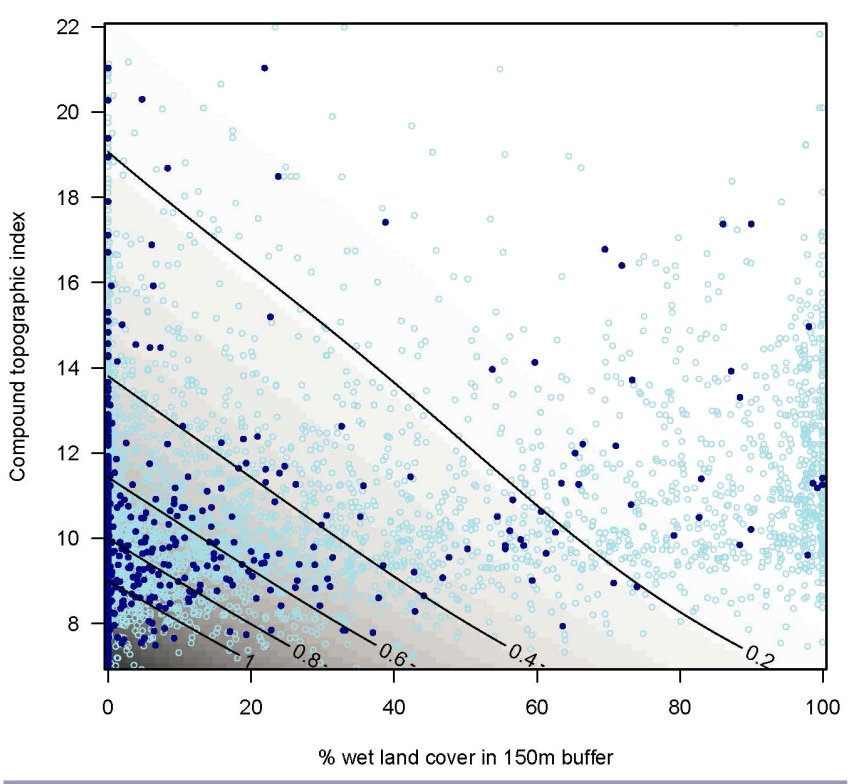

Spatial terms (latitude, longitude, climate) of different complexity were selected during all 240 bootstrap iterations (stage 7, Table 2), and predicted density showed considerable variation in space (Fig. 4A). Coefficient of variation for predicted density was highest in the Rocky Mountain Natural region and at the northwestern and southern edges of the study area (Fig. 4B). The availability of deciduous and mixed forests at the stand $\left(1 \mathrm{~km}^{2}\right)$ scale was important (100\% selection; stage 8, Table 2) irrespective of forest age. Relative abundance increased considerably with the amount of deciduous and mixed forest stands in the surrounding $1 \mathrm{~km}^{2}$ (Fig. 5). Stand-level human footprint surrounding the locations was of less importance $(23.8 \%$ model selection frequency; stage 9 , Table 2). When stand-level footprint was selected, the type of footprint was usually not important $(70 \%$ of selected footprint models were total human footprint). The linear year effect was selected in $95.8 \%$ of bootstrap iterations with an estimated $+4.17 \%$ $(90 \%$ CI: +2.67 to $+5.91 \%)$ annual population change after accounting for effects from the previous model stages.

The predicted population size of Canada Warbler in northern Alberta based on habitat supply was 395,300 males $(90 \% \mathrm{CI}$ : 331,800-498,500 males; Table 3). Habitat ranks based on density per unit area (i.e., habitat suitability) differed from those based on predicted population size because of differences in total area of each habitat class (Table 3). Older deciduous forests were predicted to support the greatest proportion $(31.9 \%)$ of Canada Warblers in our study area 
Fig. 4. Predictive map of bootstrap averaged Canada Warbler density (males/ha) in northern Alberta (A) and the coefficient of variation (B; standard deviation/mean; values are based on 240 bootstrap iterations). The mapping unit is $1 \mathrm{~km}^{2}$; base year for human footprint inventory is 2012 .

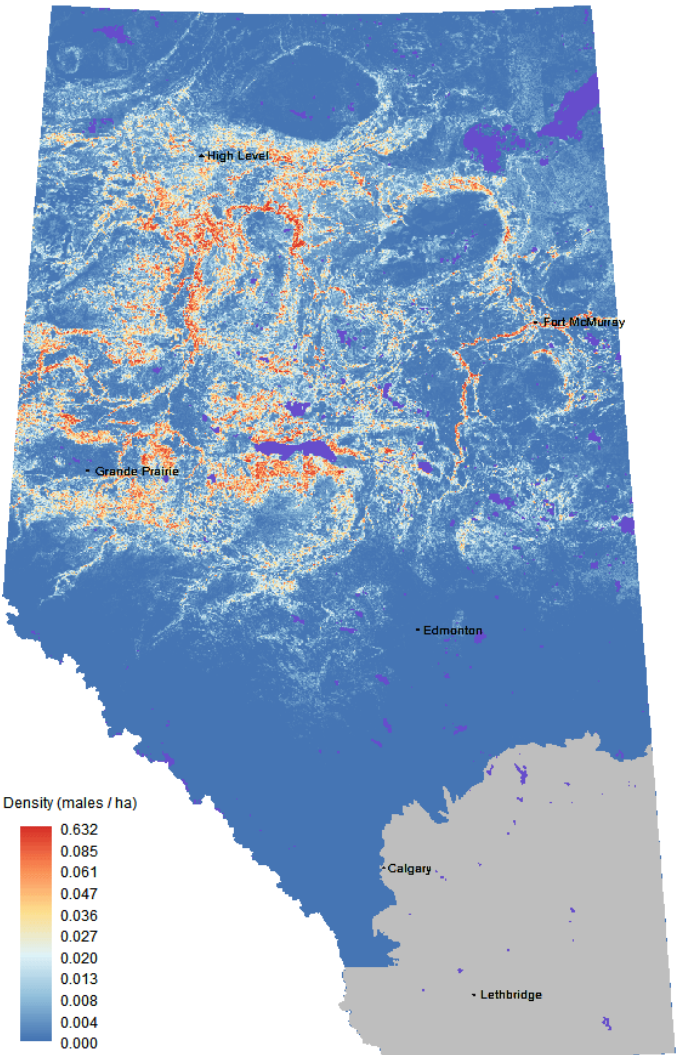

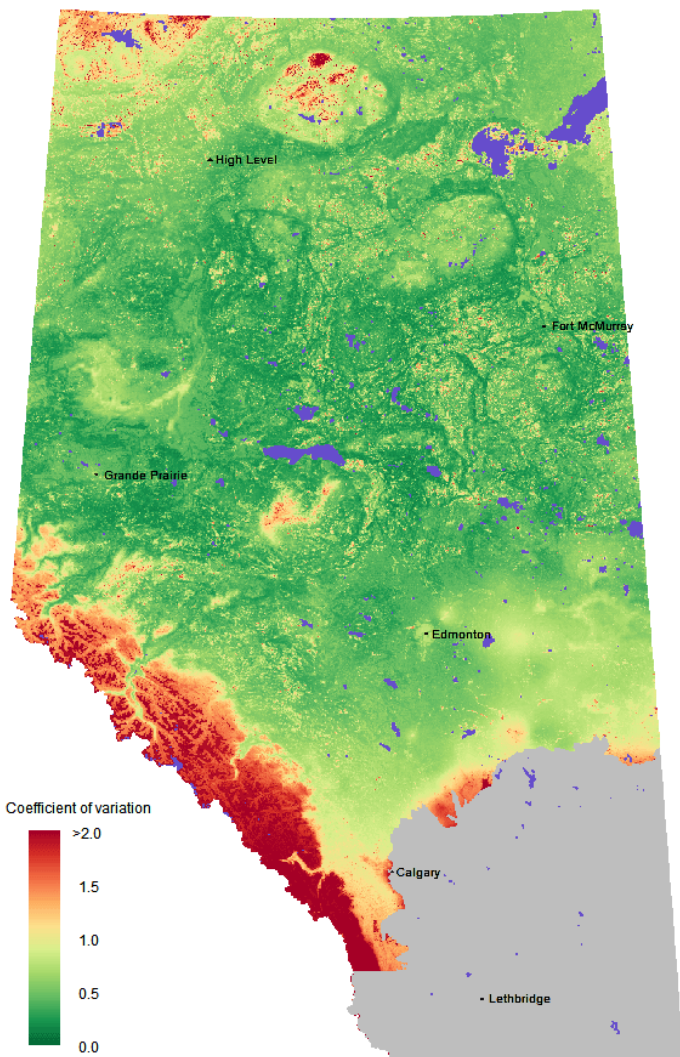

Fig. 5. Predicted relationship of Canada Warbler relative abundance as a function of percent deciduous forest at the stand $\left(1 \mathrm{~km}^{2}\right)$ scale. Shaded area indicates $90 \%$ prediction interval around the mean predicted relationship. Relative abundance is interpreted as a multiplier for local density; i.e., higher amounts of deciduous forest around a point lead to $>1$ times the local density compared with the $0 \%$ deciduous forest stand-level condition.

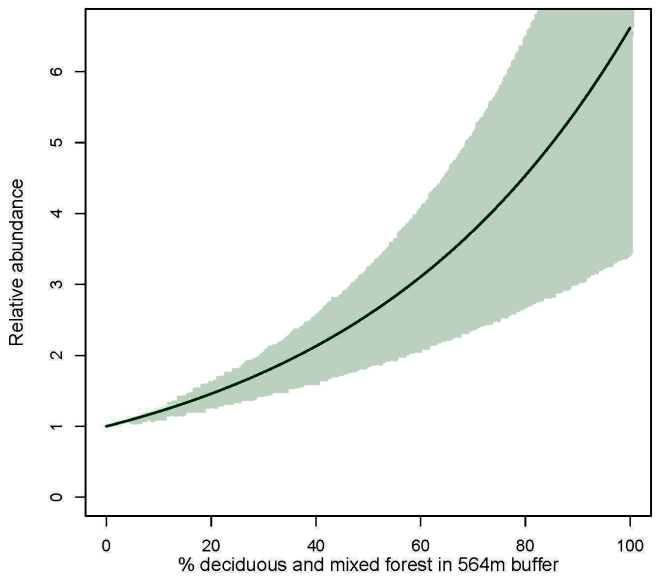

based on density and total area. Older mixed wood forests were identified as the second most important habitat class based on density. However, this habitat class was predicted to support fewer total numbers of Canada Warblers than young deciduous forests, shrubby lowlands, and swamps, and similar numbers as older black spruce, because of differences in the total area available (Table 3).

\section{DISCUSSION}

We found that habitat supporting higher densities of Canada Warbler in Alberta was locally concentrated yet broadly distributed across the province's northern boreal region (Fig. 4A). The Canada Warbler was predicted to be most commonly associated with older age classes ( $>80$ YSD) of deciduous forests, particularly near small, incised streams at the local scale, and within deciduous forest at the stand scale. Predicted density was lower in other forest types and younger age classes measured at the local scale. Similar habitat associations have been reported elsewhere for the western portion of the species range (Schieck et al. 1995, Stelfox 1995, Cooper et al. 1997, Schieck and Song 2006). However, several researchers have also reported an association of Canada Warbler with brushy edges and early seral forest in western Canada, particularly in areas with high densities of shrubs and large residual patches of large live trees that may 
provide suitable song perches (Cooper et al. 1997, Hobson and Schieck 1999, Schieck et al. 2000, Schieck and Hobson 2000, Schieck and Song 2006). Canada Warblers were detected in early seral forest in this study, typically in areas of thick shrubby regrowth near wet areas or areas with larger patches of residual forest within harvest areas with thick, shrubby regrowth rather than one or few residual trees (J.S. and J.R.B., personal observation). However, such detections were uncommon (see also Schieck et al. 2000, Schieck and Song 2006), and this forest class received limited support as suitable habitat in our models and is unlikely to support a particularly large number of birds.

Overall, the habitat associations we observed suggest that loss of older forest and loss of forested riparian areas may be partially responsible for observed declines of the Canada Warbler in Alberta's BBS data. Forest conversion, particularly along the southern fringe of the boreal forest, is the biggest threat to birds in the western boreal forest (NABCI 2012). As of 2010, $21 \%$ of Alberta's Boreal Plains Ecozone, which encompasses the majority of Alberta's northern forest, has been altered by human activity, more than half of which constitutes habitat loss to agriculture (ABMI 2012). Canada Warblers in this study responded negatively to habitat conversion from forest to most nonforest types at the local scale.

Current oil and gas practices in the western boreal forest have been predicted to further reduce numbers of Canada Warblers in this region (Carlson et al. 2009). Although forest clearing for oil and gas development reduces the amount of trees on the landscape, the effects of fragmentation from linear features and small disturbances (e.g., well sites) were not important predictors of Canada Warbler abundance in this study. Machtans (2006) found that Canada Warblers did not avoid seismic lines in the Northwest Territories but included these features within their territories. However, linear features were treated as unusable, and territory size was expanded to compensate. Considered in isolation, this result suggests fragmentation of Canada Warbler habitat in the boreal forest does not have direct negative effects on local- and stand-level Canada Warbler abundance in Alberta as long as a deciduous matrix is retained (see also ABMI 2012). Similar conclusions regarding the effects of forest fragmentation in a largely forested landscape have been made for other species of boreal birds in Alberta and elsewhere (Schmiegelow et al. 1997, Norton et al. 2000, Brotons et al. 2003, Taylor and Krawchuk 2006, Leonard et al. 2008, Whitaker et al. 2008). More precise measurements of space use by Canada Warblers in relationship to energy footprint are required, however, to fully evaluate the consequences of energy development for this species.

Historic and current land use practices in Alberta could reduce amounts of habitat where Canada Warblers are frequently detected (Schneider et al. 2003, Mahon et al. 2014). An estimated $32 \%$ of deciduous trees and $50 \%$ of older age classes of deciduous trees have been lost in Alberta compared with a landscape without human development (ABMI 2012). Current harvest strategies are meant to replicate a natural disturbance regime, which, in Alberta's boreal forest, is primarily fire. However, harvesting selectively targets old forest stands, whereas fire generally affects all age classes (Cyr et al. 2009, Lee et al. 2009). The result is that older age classes are underrepresented and younger age classes are overrepresented on the landscape compared with a landscape without harvesting. Harvesting and regeneration practices that increase the vigor and representation of coniferous trees at the expense of deciduous trees in early seral forests (Lieffers et al. 2008) will further contribute to a loss of older deciduousdominated forest. If older deciduous forest and forested riparian areas continue to be reduced as indicated by historical trends (Schieck et al. 2014), Canada Warblers are expected to further decline in Alberta based on the habitat associations found by our models.

Our results suggest that land use planning aimed at conserving Canada Warbler habitat in Alberta should focus on minimizing permanent loss through conversion of forested areas to other land uses, retaining larger areas of older deciduous forest adjacent to incised streams, and implementing alternative forest harvesting strategies. Habitat conversion is of particular concern along the southern boreal fringe, where Canada Warblers are predicted to be locally abundant (Fig. 4A) and urban and agriculture expansion are encroaching on the forest (Schieck et al. 2014). Oil sands mining, which currently operates in the northeastern portion of the province, also results in loss of forest cover (ABMI 2013b). Canada Warblers are predicted to be at lower densities in much of this region, with notable exceptions in concentrations of older deciduous forest along major river systems (Fig. 4A).

The current forestry guidelines relating to rotation age and forest retention, particularly retention adjacent to streams, are unlikely to provide sufficient protection for maintenance of Canada Warbler habitat. Current guidelines require retention of 30- to 60-m treed buffers for only small and large permanent streams, respectively (ASRD 2008). Treed buffers along narrow intermittent and ephemeral streams are not required in harvest areas, but such areas are important to Canada Warbler. We suggest that increasing the width of buffers adjacent to streams in older deciduous stands should help preserve habitats where Canada Warblers are frequently detected. The width of buffers necessary to support local populations of Canada Warblers is unclear, although this is being investigated (A. Hunt, E. Bayne, and $\mathrm{S}$. Hache, unpublished data). Under current guidelines, harvest is typically initiated during the mature stage (76-125 years; Lee 2002, ASRD 2008), with a minimum rotation age for deciduous forest of 60 years or fewer dependent on the forest management area. This minimum rotation age and an "oldest-first" principle in general for initial harvest are anticipated to substantially reduce the amount of old forest over extensive areas of boreal Alberta (Schneider 2002, Cyr et al. 2009, Mahon et al. 2014). Extending the harvest rotation age to $>76$ years for at least a portion of the deciduous forest would maintain greater amounts of older forest on the landscape to support larger Canada Warbler populations.

We found that the ranking of land cover types based on population density and percentage of the total Alberta population differed. Young $(<80$ years) deciduous forests had lower densities of Canada Warblers compared with older deciduous stands but were still expected to harbor $16.4 \%$ of the total population. This result implies that management of habitats that is suboptimal from a purely density standpoint might prove beneficial for a species of concern when the spatial distribution, amount, and availability of that habitat are considered as well. It is important to note that we did not assess the association between habitat and demography, which is crucial to better understanding 
potential population trajectories under alternative land use scenarios (Johnson 2007). In New Hampshire, the Canada Warbler demonstrated similar reproductive performance in early and late seral habitats as long as the understory structure was similar (Hallworth et al. 2008a, b, Reitsma et al. 2008). In contrast, Canada Warblers were less persistent in younger forest stands in Minnesota, suggesting reproductive success may have been lower in these stands (Grinde and Niemi 2016). Land use practices that support retention or recruitment of dense shrubby understory could further enhance the conservation value of managed forests for Canada Warblers. However, a recent study in Alberta found that the Canada Warbler has smaller territories and lower fecundity in areas with high shrub cover, possibly because of increased resource competition (Flockhart et al. 2016). Further research is needed to determine whether early seral habitats function as reproductive sources or sinks in western boreal forests, some of which is ongoing (A. Hunt, E. Bayne, and S. Hache, unpublished data). Improved spatial data on understory vegetation would help refine the relationship with shrub density and further inform estimates of habitat potential. Experimental manipulations conducted within an adaptive management framework, and an analysis of Canada Warbler response to landscape patterns at more extensive scales than those included in the present study, are warranted to support long-term management strategies.

We estimated the Canada Warbler breeding population in Alberta in 2012 to be 395,300 males. Assuming a 1:1 sex ratio, our estimate is $465 \%$ of the population size estimate by Partners in Flight (170,000 individuals; PIF Science Committee 2013). The difference between the two estimates is only partly explained by the 1.9 ratio of effective area sampled based on the maximum detection distance (MDD) used by PIF (MDD $=100 \mathrm{~m}$, PIF Science Committee 2013) and the average effective detection radius (EDR) of $73.06 \mathrm{~m}$ in our study $\left(\mathrm{MDD}^{2} / \mathrm{EDR}^{2}\right.$, see Matsuoka et al. 2012; note that Matsuoka et al. 2012 reported a 9.9 ratio based on the 2004 version of MDD and maximum EDR, which were $200 \mathrm{~m}$ and $63.7 \mathrm{~m}$, respectively). Other factors, such as roadside BBSs used by PIF compared with our integrated (on and off road) data set and differences in time adjustment versus availability estimates, could also contribute to the difference (Thogmartin et al. 2006).

The estimated $+4.2 \%$ annual increase is considerably higher than the reported $-3.74 \%$ long-term $(90 \%$ credible intervals: $-7.8 \%$ to $-0.262 \%$ ) or $-4.74 \%$ short-term $(90 \%$ credible intervals: $-15 \%$ to $+2 \%$ ) trend in Alberta based on BBSs (Environment Canada 2014). The haphazard sampling in our data set required statistical control for the types of habitats and land use sampled each year. Thus, our year effect estimate does not include population change that would be caused by changes in land cover. Therefore, the different estimates might not be directly comparable. The discrepancy between the estimates may also be partly because of differences in spatial distribution and habitats sampled by roadside (i.e., BBS) versus integrated data sets. Roads by their very nature are not often found in steep terrain and road builders make efforts to avoid streams, resulting in lower numbers of detections on roads compared with detections that may occur away from roads. It remains unclear whether the heterogeneous nature of our integrated data set is more representative of boreal Alberta or if a few influential long-term projects in our data set are driving our population trend estimate. For example, a similar increase in Canada Warbler populations has been observed in recent years at the Calling Lake long-term monitoring project ( $\mathrm{F}$. K.A.S. and E.M.B., personal observation). Population trend estimates for Canada Warblers from repeated surveys at the same location in the boreal region are elusive because of the challenges of collecting large-scale, representative, off-road sampling with yearly revisits to the same locations. Our subsampling approach should have minimized the risk that long-term sampling locations like Calling Lake drive this pattern. However, the sensitivity of population trend estimates from integrated data sets to sampling methodology (on/off road) and to influential observations requires further study. The Canada Warbler population in Alberta represents $4.5 \%$ of the global population of the species (PIF Science Committee 2013) and a $+4.2 \%$ annual increase in Alberta might be negligible for a decreasing global population.

Effective management for species at risk requires a robust understanding of species-specific habitat needs and how these habitat requirements may be affected by natural and anthropogenic disturbance, and by management decisions. Canada's boreal region supports the most extensive intact forests in the world (Potapov et al. 2008). However, these forests are undergoing significant changes associated with escalating resource development pressures. Boreal forests in Alberta are experiencing among the highest rates of change in the country, raising concerns that species sensitive to such changes may be increasingly at risk in the province (Schneider 2002, Lee et al. 2010, Venier et al. 2014). For broad-ranging species, both the requirements and responses may vary across the species distribution. Vulnerable species such as the Canada Warbler require special consideration when developing management strategies, particularly while opportunities exist to halt or at least slow population declines through proactive implementation of practices designed to address habitat needs. Our results suggest that Canada Warbler populations may not be resilient to some of the changes occurring in boreal forests of Alberta, but that changes to harvesting regimes could improve outcomes. Regionally specific management guidelines based on our results can enhance broader conservation policy for this and other species.

Responses to this article can be read online at: http://www.ace-eco.org/issues/responses.php/916

\section{Acknowledgments:}

Comments from the Associate Editor and two anonymous reviewers improved the quality of our manuscript. We thank Daiyuan Pan and Diana Stralberg for help in geospatial summaries required for the modeling, and Patricia Fontaine for managing the Boreal Avian Modelling Project database. This research was enabled in part by support provided by WestGrid (http://www.westgrid.ca), Compute Canada Calcul Canada (http://www.computecanada.ca), the Alberta Conservation Association, and the Environment and Climate Change Canada Habitat Stewardship Program. We acknowledge the Boreal Avian Modelling Project members, avian and biophysical data partners, and funding agencies (including the 
Joint Oil Sands Monitoring Program and Environment Canada), listed in full at www.borealbirds.calindex.phplacknowledgements. No funders had any input into the content of the manuscript, nor required approval prior to submission or publication.

\section{LITERATURE CITED}

Alberta Biodiversity Monitoring Institute (ABMI). 2012. The status of landbirds in Alberta's boreal plains ecozone: preliminary assessment. AMBI, University of Alberta, Edmonton, Alberta, Canada. [online] URL: http://abmi.ca/home/publications/201-250/221. html

Alberta Biodiversity Monitoring Institute(ABMI). 2013a. ABMI human footprint inventory for 2012 conditions (version 3). AMBI, University of Alberta, Edmonton, Alberta, Canada. [online] URL: ftp://ftp.public.abmi.ca/GISProduct/HumanFootprint/2012/ ABMI_Guide_HF2012_Version3_Public.pdf

Alberta Biodiversity Monitoring Institute (ABMI). 2013b. The status of biodiversity in the Athabasca Oil Sands Area: preliminary assessment. AMBI, University of Alberta, Edmonton, Alberta, Canada. [online] URL: http://www.abmi.ca

Alberta Biodiversity Monitoring Institute (ABMI). 2015. Alberta backfilled wall-to-wall vegetation layer (version 5) metadata. AMBI, University of Alberta, Edmonton, Alberta, Canada. [online] URL: http://ftp.public.abmi.ca/species.abmi.ca/geospatial/ vegetation/2012_w2w_Backfilled_LayerV5_Metadata_2.docx

Alberta Environment and Sustainable Resource Development (AESRD) and Alberta Conservation Association (ACA). 2014. Status of the Canada Warbler (Cardellina canadensis) in Alberta. Alberta Wildlife Status Report No. 70. Alberta Environment and Sustainable Resource Development, Edmonton, Alberta, Canada.

Alberta Sustainable Resource Development (ASRD). 2008. Alberta timber harvest planning and operating ground rules framework for renewal. Public Lands and Forests Division, Forest Management Branch, Edmonton, Alberta, Canada.

Anielski, M., and S. Wilson. 2009. Counting Canada's natural capital: assessing the real value of Canada's boreal ecosystems. Canadian Boreal Initiative and Pembina Institute, Ottawa, Ontario, Canada.

Bayne, E., L. Leston, C. L. Mahon, P. Sólymos, C. Machtans, H. Lankau, J. R. Ball, S. L. Van Wilgenburg, S. G. Cumming, T. Fontaine, F. K. A. Schmiegelow, and S. J. Song. 2016. Boreal bird abundance estimates within different energy sector disturbances vary with point count radius. Condor 118:376-390. http://dx.doi. org/10.1650/CONDOR-15-126.1

Becker, D. A., P. Bohall Wood, and P. D. Keyser. 2012. Canada Warbler use of harvested stands following timber management in the southern portion of their range. Forest Ecology and Management 276:1-9. http://dx.doi.org/10.1016/j.foreco.2012.03.018

Blancher, P., and J. Wells. 2005. The boreal forest region: North America's bird nursery. Boreal Songbird Initiative and Canadian Boreal Initiative, Ottawa, Ontario, Canada.

Breiman, L. 1996. Bagging predictors. Machine Learning 24:123-140. http://dx.doi.org/10.1007/BF0005865510.1525/ auk.2008.07115
Brotons, L., M. Mönkkönen, and J. L. Martin. 2003. Are fragments islands? Landscape context and density-area relationships in boreal forest birds. American Naturalist 162:343-357. http://dx.doi.org/10.1086/376887

Canadian Endangered Species Conservation Council (CESCC). 2011. Wild species 2010: the general status of species in Canada. National General Status Working Group. [online] URL: http:// publications.gc.ca/collections/collection_2011/ec/CW70-7-2010-eng. pdf

Carlson, M., E. Bayne, and B. Stelfox. 2009. Assessing the future of wildlife impacts on conservation and development in the Mackenzie watershed. Pages 531-540 in T. D. Rich, C. Arizmendi, D. Demarest, and C. Thompson, editors. Tundra to tropics: connecting birds, habitats and people. Proceedings of the Fourth International Partners in Flight Conference. Partners in Flight, McAllen, Texas, USA.

Chandler, R., and J. Hepinstall-Cymerman. 2016. Estimating the spatial scales of landscape effects on abundance. Landscape Ecology 31:1383-1394. http://dx.doi.org/10.1007/s10980-016-0380$\mathrm{Z}$

Cooper, J. M., K. A. Enns, and M. G. Shepard. 1997. Status of the Canada Warbler in British Columbia. Wildlife Working Report No. WR-81. Ministry of Environment, Lands and Parks, Wildlife Branch, Victoria, British Columbia, Canada.

COSEWIC. 2008. COSEWIC assessment and status report on the Canada Warbler Wilsonia canadensis in Canada. Committee on the Status of Endangered Wildlife in Canada, Ottawa, Ontario, Canada. [online] URL: https://www.registrelep-sararegistry.gc. ca/virtual_sara/files/cosewic/sr_canada_warbler_0808_e.pdf

Cyr, D., S. Gauthier, Y. Bergeron, and C. Carcaillet. 2009. Forest management is driving the eastern North American boreal forest outside its natural range of variability. Frontiers in Ecology and the Environment 7:519-524. http://dx.doi.org/10.1890/080088

Daly, C., W. P. Gibson, G. H. Taylor, G. L. Johnson, and P. Pasteris. 2002. A knowledge-based approach to the statistical mapping of climate. Climate Research 22:99-113. http://dx.doi.org/10.3354/ cr022099

Efron, B. 2014. Estimation and accuracy after model selection. Journal of the American Statistical Association 109:991-1007. http://dx.doi.org/10.1080/01621459.2013.823775

Environment Canada. 2014. North American breeding bird survey - Canadian trends website, data-version 2012. Environment Canada, Gatineau, Quebec, Canada. [online] URL: http://www. ec.gc.ca/ron-bbs/P004/A001/?lang=e\&m=s\&r=CAWA\&p=-

Environment Canada. 2016a. Recovery strategy for the Olive-sided Flycatcher (Contopus cooperi) in Canada. Species at Risk Act Recovery Strategy Series. Environment Canada, Ottawa, Ontario, Canada.

Environment Canada. 2016b. Recovery strategy for the Canada Warbler (Cardellina canadensis) in Canada. Species at Risk Act Recovery Strategy Series. Environment Canada, Ottawa, Ontario, Canada.

Environment and Sustainable Resource Development (ESRD). 2010. General status of Alberta wild species 2010. Environment and Sustainable Resource Development, Edmonton, Alberta, 
Canada. [online] URL: http://aep.alberta.ca/fish-wildlife/speciesat-risk/albertas-species-at-risk-strategy/general-status-of-albertawild-species-2010/default.aspx

Flockhart, D., G. W. Mitchell, R. G. Krikun, and E. M. Bayne. 2016. Factors driving territory size and breeding success in a threatened migratory songbird, the Canada Warbler. Avian Conservation and Ecology 11(2):4. http://dx.doi.org/10.5751/ ACE-00876-110204

George, T. L., and D. S. Dobkin. 2002. Introduction: habitat fragmentation and western birds. Studies in Avian Biology 25:4-7.

Gessler, P. E., I. D. Moore, N. J. McKenzie, and P. J. Ryan. 1995. Soil-landscape modeling and spatial prediction of soil attributes. International Journal of GIS 9:421-432.

Goodnow, M. L., and L. R. Reitsma. 2011. Nest-site selection in the Canada Warbler (Wisonia canadensis) in central New Hampshire. Canadian Journal of Zoology 89:1172-1177. http:// dx.doi.org/10.1139/z11-094

Grinde, A. R., and G. J. Niemi. 2016. Influence of landscape, habitat, and species co-occurrence on occupancy dynamics of Canada Warbler. Condor 118:513-531. http://dx.doi.org/10.1650/ CONDOR-15-168.1

Hallworth, M., P. M. Benham, J. D. Lambert, and L. Reitsma. 2008b. Canada Warbler (Wilsonia canadensis) breeding ecology in young forest stands compared to a red maple (Acer rubrum) swamp. Forest Ecology and Management 255:1353-1358. http:// dx.doi.org/10.1016/j.foreco.2007.10.045

Hallworth, M., A. Ueland, E. Anderson, J. D. Lambert, and L. Reitsma. 2008a. Habitat selection and site fidelity of Canada Warblers (Wilsonia canadensis) in central New Hampshire. Auk 125:880-888. http://dx.doi.org/10.1525/auk.2008.07115

Hijmans, R. J., S. E. Cameron, J. L. Parra, P. G. Jones, and A. Jarvis. 2005. Very high resolution interpolated climate surfaces for global land areas. International Journal of Climatology 25:1965-1978. http://dx.doi.org/10.1002/joc.1276

Hobson, K. A., and J. Schieck. 1999. Changes in bird communities in boreal mixedwood forest: harvest and wildfire effects over 30 years. Ecological Applications 9:849-863. http://dx.doi. org/10.1890/1051-0761(1999)009[0849:CIBCIB]2.0.CO;2

Johnson, D. H. 1980. The comparison of usage and availability measurements for evaluation resource preference. Ecology 61:65-71. http://dx.doi.org/10.2307/1937156

Johnson, M. D. 2007. Measuring habitat quality: a review. Condor 109:489-504. http://dx.doi.org/10.1650/8347.1

Lambert, J. D., and S. D. Faccio. 2005. Canada Warbler: population status, habitat use, and forest stewardship guidelines for northeastern forests. Vermont Institute of Natural Sciences (VINS) Technical Report 05-4. VINS, Quechee, Vermont, USA.

Lee, P. 2002. Stages of forest succession. Chapter 3 in S. J. Song, editor. Ecological basis for stand management: a summary and synthesis of ecological responses to wildfire and harvesting in boreal forests. Alberta Research Council, Vegreville, Alberta, Canada.

Lee, P., M. Hanneman, J. Gysbers, and R. Cheng. 2009. The last great intact forests of Canada: atlas of Alberta. Part 1: where are the last great intact forest landscapes of Alberta and where is the best of what's left? Global Forest Watch, Edmonton, Alberta, Canada.

Lee, P. G., M. Hanneman, and J. D. Gysbers. 2010. Industrialcaused changes to Canada's forest frontier: 1990-2001. Global Forest Watch Canada 10th Anniversary Publication No. 10. Global Forest Watch Canada, Edmonton, Alberta, Canada.

Leonard, T. D., P. D. Taylor, and I. G. Warkentin. 2008. Landscape structure and spatial scale affect space use by songbirds in naturally patchy and harvested boreal forests. Condor 110:467-481. http://dx.doi.org/10.1525/cond.2008.8512

Lieffers, V. J., G. W. Armstrong, K. J. Stadt, and E. H. Marenholtz. 2008. Forest regeneration standards: are they limiting management options for Alberta's boreal mixedwoods? Forestry Chronicle 84:76-82. http://dx.doi.org/10.5558/tfc84076-1

Machtans, C. S. 2006. Songbird response to seismic lines in the western boreal forest: a manipulative experiment. Canadian Journal of Zoology 84:1421-1430. http://dx.doi.org/10.1139/ z06-134

Mahon, C. L., E. M. Bayne, P. Sólymos, S. M. Matsuoka, M. Carlson, E. Dzus, F. K. A. Schmiegelow, and S. J. Song. 2014. Does expected future landscape condition support proposed population objectives for boreal birds? Forest Ecology and Management 312:28-39.

Marques, T. A., S. T. Buckland, D. L. Borchers, D. Tosh, and R. A. McDonald. 2010. Point transect sampling along linear features. Biometrics 66:1247-1255. http://dx.doi.org/10.1111/ j.1541-0420.2009.01381.X

Matsuoka, S. M., E. M. Bayne, P. Sólymos, P. C. Fontaine, S. G. Cumming, F. K. A. Schmiegelow, and S. A. Song. 2012. Using binomial distance-sampling models to estimate the effective detection radius of point-counts surveys across boreal Canada. Auk 129:268-282. http://dx.doi.org/10.1525/auk.2012.11190

Moore, I. D., P. E. Gessler, G. A. Nielsen, and G. A. Petersen, 1993. Terrain attributes: estimation methods and scale effects. Pages 189-214 in A. J. Jakeman, M. B. Beck, and M. McAleer, editors. Modeling change in environmental systems. John Wiley and Sons, London, UK.

Morante-Filho J. C., D. Faria, E. Mariano-Neto, and J. Rhodes. 2015. Birds in anthropogenic landscapes: the responses of ecological groups to forest loss in the Brazilian Atlantic Forest. PLoS ONE 10(6):e0128923. http://dx.doi.org/10.1371/journal. pone. 0128923

North American Bird Conservation Initiative (NABCI) Canada. 2012. The State of Canada's Birds, 2012. Environment Canada, Ottawa, Ontario, Canada. [online] URL: http://www. stateofcanadasbirds.org

Norton, M. R., S. J. Hannon, and F. K. A. Schmiegelow. 2000. Fragments are not islands: patch vs landscape perspectives on songbird presence and abundance in a harvested boreal forest. Ecography 23:209-223. http://dx.doi.org/10.1111/j.1600-0587.2000. tb00277.x

Partners in Flight (PIF) Science Committee. 2013. PIF population estimates database, version 2.0. [online] URL: http://rmbo.org/ pifpopestimates 
Pavalacky, D. C., Jr., H. P. Possingham, and A. W. Goldizen. 2015. Integrating life history traits and forest structure to evaluate the vulnerability of rainforest birds along gradients of deforestation and fragmentation in eastern Australia. Biological Conservation 188:89-99. http://dx.doi.org/10.1016/j.biocon.2014.10.020

Potapov, P., A. Yaroshenko, S. Turubanova, M. Dubinin, L. Laestadius, C. Thies, D. Aksenov, A. Egorov, Y. Yesipova, I. Glushkov, M. Karpachevskiy, A. Kostikova, A. Manisha, E. Tsybikova, and I. Zhuravleva. 2008. Mapping the world's intact forest landscapes by remote sensing. Ecology and Society 13(2):51. [online] URL: http://www.ecologyandsociety.org/vol13/iss2/ $\operatorname{art51/}$

R Core Team. 2016. R: a language and environment for statistical computing. R Foundation for Statistical Computing, Vienna, Austria. [online] URL: https://www.R-project.org/

Reitsma, L., M. Goodnow, M. T. Hallworth, and C. J. Conway. 2010. Canada Warbler (Cardellina canadensis). In A. Poole and F. Gill, editors. Birds of North America. Number 421. Academy of National Sciences, Philadelphia, Pennsylvania, USA, and American Ornithologists' Union, Washington, D.C., USA. [online] URL: https://birdsna.org/Species-Account/bna/species/ canwar/introduction

Reitsma, L. R., M. T. Hallworth, and P. M. Benham. 2008. Does age influence territory size, habitat selection, and reproductive success of male Canada Warblers in central New Hampshire? Wilson Journal of Ornithology 120:446-454. http://dx.doi. org/10.1676/07-109.1

Rich, T. D., C. J. Beardmore, H. Berlanga, P. J. Blancher, M. S. W. Brandstreet, G. S. Butcher, D. W. Demarest, E. H. Dunn, W. C. Hunter, E. E. Inigo-Elias, J. A. Kenned, A. M. Martell, A. O. Panjabi, D. N. Pashley, K. V. Rosenberg, C. M. Rustay, J. S. Wendt, and T. C. Will. 2004. Partners in Flight. North American Landbird Conservation Plan. Cornell Lab of Ornithology, Ithaca, New York, USA. [online] URL: https://www.partnersinflight.org/wpcontent/uploads/2016/07/PIF-Landbird-Conservation-Plan-2004. pdf

Robin, X., N. Turck, A. Hainard, N. Tiberti, F. Lisacek, J.-C. Sanchez, and M. Müller. 2011. pROC: an open-source package for $\mathrm{R}$ and $\mathrm{S}+$ to analyze and compare ROC curves. $B M C$ Bioinformatics 12:77. http://dx.doi.org/10.1186/1471-2105-12-77

Robinson, W. D., and T. W. Sherry. 2012. Mechanisms of avian population decline and species loss in tropical forest fragments. Journal of Ornithology 153(Suppl 1):141-152. http://dx.doi. org/10.1007/s10336-011-0806-y

Rudd, W. A., K. F. Beazley, S. J. Cooke, E. Fleishman, D. E. Lane, M. B. Mascia, R. Roth, G. Tabor, J. A. Bakker, T. Bellefontaine, D. Berteaux, B. Cantin, K. G. Chaulk, K. Cunningham, R. Dobell, E. Fast, N. Ferrara, C. S. Findlay, L. K. Hallstrom, T. Hammond, L. Hermanutz, J. A. Hutchings, K. E. Lindsay, T. J. Martha, V. M. Nguyen, G. Northey, K. Prior, S. RamirezSanchez, J. Rice, D. J. H. Sleep, N. D. Szabo, G. Trottier, J.-P. Toussaint, and J.-P. Veilleux. 2011. Generation of priority research questions to inform conservation policy and management at a national level. Conservation Biology 25:476-484. http://dx.doi.org/10.1111/j.1523-1739.2010.01625.x
Sauer, J. R., J. E. Hines, J. E. Fallon, K. L. Pardieck, D. J. Ziolkowski, Jr., and W. A. Link. 2014. The North American Breeding Bird Survey, results and analysis 1966-2013. Version 01.30.2015. USGS Patuxent Wildlife Research Center, Laurel, Maryland, USA. [online] URL: http://www.mbr-pwrc.usgs.gov/ bbs/bbs.html

Schieck, J., and K. A. Hobson. 2000. Bird communities associated with live residual tree patches within cut blocks and burned habitat in mixedwood boreal forests. Canadian Journal of Forest Research 30:1281-1295. http://dx.doi.org/10.1139/x00-061

Schieck, J., M. Nietfeld, and J. B. Stelfox. 1995. Differences in bird species richness and abundance among three successional stages of aspen-dominated boreal forests. Canadian Journal of Zoology 73:1417-1431. http://dx.doi.org/10.1139/z95-167

Schieck, J., P. Sólymos, and D. Huggard. 2014. ABMI science letters: human footprint in Alberta. AMBI, University of Alberta, Edmonton, Alberta, Canada. [online] URL: http://www.abmi.ca/ home/publications/351-400/364.html

Schieck, J., and S. J. Song. 2006. Changes in bird communities throughout succession following fire and harvest in boreal forests of western North America: literature review and meta-analyses. Canadian Journal of Forest Research 36:1299-1318. http://dx.doi. org/10.1139/x06-017

Schieck, J., K. Stuart-Smith, and M. Norton. 2000. Bird communities are affected by amount and dispersion of vegetation retained in mixedwood boreal forest harvest areas. Forest Ecology and Management 126:239-254. http://dx.doi.org/10.1016/S0378-1127 (99)00088-2

Schmiegelow, F. K. A., C. S. Machtans, and S. J. Hannon. 1997. Are boreal birds resilient to forestry fragmentation? An experimental study of short-term community responses. Ecology 78:1914-1932. http://dx.doi.org/10.1890/0012-9658(1997)078[1914: ABBRTF]2.0.CO;2

Schmiegelow, F. K. A., and M. Mönkkönen. 2002. Habitat loss and fragmentation in dynamic landscapes: avian perspectives from the boreal forest. Ecological Applications 12:375-389.

Schmiegelow, F. K. A., and M.-A. Villard. 2009. Conservation of boreal birds and the case for resilience: does it pass the test? Avian Conservation and Ecology 4(1):4. [online] URL: http://www.aceeco.org/vol4/iss1/art4/

Schneider, R. R. 2002. Alternative futures: Alberta's boreal forest at the crossroads. Federation of Alberta Naturalists, Edmonton, Alberta, Canada.

Schneider, R. R., B. J. Stelfox, S. Boutin, and S. Wasel. 2003. Managing the cumulative impacts of land-uses in the western Canadian sedimentary basin: a modeling approach. Conservation Ecology 7(1):8.

Sólymos, P. 2009. Processing ecological data in R with the mefa package. Journal of Statistical Software 29:1-28. http://dx.doi. org/10.18637/jss.v029.i08

Sólymos, P. 2016. QPAD version 3 documentation. Technical Report. Boreal Avian Modelling Project, Edmonton, Alberta, Canada. [online] URL: http://www.borealbirds.ca/files/ Solymos2016.QPAD_v3_report_2.pdf 
Sólymos, P., S. M. Matsuoka, E. M. Bayne, S. R. Lele, P. Fontaine, S. G. Cumming, D. Stralberg, F. K. A. Schmiegelow, and S. J. Song. 2013. Calibrating indices of avian density from nonstandardized survey data: making the most of a messy situation. Methods in Ecology and Evolution 4:1047-1058. http://dx.doi. org/10.1111/2041-210X.12106

Stelfox, J. B. 1995. Relationships between stand age, stand structure, and biodiversity in aspen mixedwood forests in Alberta. Alberta Environmental Centre, Vegreville, Alberta, Canada, and Canadian Forest Service, Edmonton, Alberta, Canada.

Streby, H. M., and D. E. Andersen. 2013. Testing common assumptions in studies of songbird nest success. Ibis 155:327-337. http://dx.doi.org/10.1111/ibi.12018

Taylor, P. D., and M. A. Krawchuk. 2006. Scale and sensitivity of songbird occurrence to landscape structure in a harvested boreal forest. Avian Conservation and Ecology 1(1):5 [online] URL: http://www.ace-eco.org/vol1/iss1/art5/

Thogmartin, W. E., F. P. Howe, F. C. James, D. H. Johnson, E. T. Reed, J. R. Sauer, and F. R. Thompson, III. 2006. A review of the population estimation approach of the North American Landbird Conservation Plan. Auk 123:892-904. http://dx.doi. org/10.1642/0004-8038(2006)123[892:AROTPE]2.0.CO;2

Venier, L. A., I. D. Thompson, R. Fleming, J. Malcolm, I. Aubin, J. A. Trofymow, D. Langor, R. Sturrock. C. Patry, R. O. Outerbridge, S. B. Holmes, S. Haeussler, L. De Grandpre, H. Y. H. Chen, E. Bayne, A. Arsenault, and J. P. Brandt. 2014. Effects of natural resource development on the terrestrial biodiversity of Canadian boreal forests. Environmental Review 22:457-490. http:// dx.doi.org/10.1139/er-2013-0075

Virkkala, R. 2016. Long-term decline of southern boreal forest birds: consequence of habitat alteration or climate change? Biodiversity and Conservation 25:151-167. http://dx.doi. org/10.1007/s10531-015-1043-0

Wang, T., A. Hamann, D. L. Spittlehouse, and T. Q. Murdock. 2012. ClimateWNA-high-resolution spatial climate data for western North America. Journal of Applied Meteorology and Climatology 51:16-29. http://dx.doi.org/10.1175/JAMC-D-11-043.1

Wells, J. V., and P. J. Blancher. 2011. Global role for sustaining bird populations. Studies in Avian Biology 41:7-21.

Whitaker, D. M., P. D. Taylor, and I. G. Warkentin. 2008. Survival of adult songbirds in boreal forest landscapes fragmented by clearcuts and natural openings. Avian Conservation and Ecology 3(1):5. [online] URL: http://www.ace-eco.org/vol3/iss1/art5/

Editor-in-Chief: Ryan Norris Subject Editor: Andrew Campomizzi
Sponsored by the Society of Canadian Ornithologists and Bird Studies Canada Parrainée par la Société des ornithologistes du Canada et Études d'oiseaux Canada

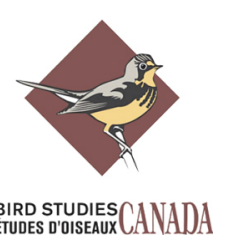

